\title{
OSSOS DO OFíCIO
}

\section{Peter Fry}

\section{Universidade Federal do Rio de Janeiro - Brasil}

O esplêndido artigo de Marcos Chor Maio e Ricardo Ventura Santos descreve a analisa o processo de identificação "racial" desenvolvido pela Universidade de Brasília no contexto da introdução de cotas raciais nas universidades brasileiras. Através de fotografias e entrevistas, comissões da UnB, compostas de ativistas negros, membros de ONGs, sociólogos e antropólogos, examinam a aparência exterior e o interior psicológico dos candidatos na inglória tarefa de dividi-los em duas categorias estanques: os que têm direito às cotas e os que não têm; os negros e os não negros. Assim fazendo, imaginam e ritualizam (e ajudam a produzir) um Brasil de duas "raças" apenas. Os mulatos, morenos, caboclos, etc. deixaram de existir, vítimas do que José Murilo de Carvalho denominou "genocídio racial estatístico" (Carvalho, 2004). Muito apropriadamente, os autores denominam esse processo de uma "pedagogia racial", poderosa muito além dos muros da UnB, justamente por essa universidade se encontrar tão próxima ao centro material e simbólico do poder da República.

Os autores concentram a análise sobre o papel da antropologia na detecção e legitimação de identidades "raciais" e "étnicas". ${ }^{1}$ Fica evidente que há divergências no campo da antropologia no que diz respeito às cotas, mesmo se todos parecem preocupados com os métodos de identificação adotados pela UnB. Tendo escrito o documento que instaurou o processo de adoção de cotas "raciais" na UnB, José Jorge de Carvalho e Rita Laura Segato manifestaram "júbilo" quando foram aprovadas. Desaprovaram, porém, o processo das fotografias, preferindo aderir à auto-atribuição racial, seguindo a Convenção 169 da OIT. A Comissão de Relações Étnicas e Raciais (Crer) da Associação Brasileira de Antropologia (ABA) se posicionou criticamente em relação aos métodos de classificação da UnB, mas não se manifestou sobre a política de cotas em si. Outros, eu inclusive, apontam para os possíveis efeitos racializadores sobre o conjunto da sociedade a longo prazo.

${ }^{1}$ Coloco os dois termos entre aspas porque não os considero conceitos analíticos. São conceitos que pertencem firmemente aos reinos da cultura e da política. 
Maio e Santos relacionam a atuação dos antropólogos na classificação "racial” dos candidatos à UnB com o envolvimento da antropologia brasileira na preparação de laudos sobre terras indígenas. De fato isso não mais ocorre tão formalmente, pois desde maio de 2003 a Funai reconhece apenas a auto-atribuição dos índios. ${ }^{2}$

Parece, então, que alguns antropólogos se encontram no epicentro da inflexão racial e étnica que os autores apontam. Como parte dos "ossos do oficio", os antropólogos se tornaram os cartógrafos da diferença cultural, "racial" e "ética", não apenas documentando os outros, mas participando ativamente na construção social destes. Assim, determinados antropólogos avançam um processo de celebração das supostas diferenças "raciais" ou "étnicas" do Brasil, reconhecendo e celebrando a "diversidade", palavra de ordem do mundo globalizado. ${ }^{3}$

Sem querer fazer qualquer juízo político ou moral sobre essa inflexão, espero que o texto de Maio \& Santos nos incentive a olhar mais para nós mesmos (nós, os outros) à luz da nossa própria teoria antropológica.

\section{Referências}

ASSOCIAÇÃO BRASILEIRA DE ANTROPOLOGIA. Informativo, n. 014/2003, 13 jun. 2003. Disponível em: <http://www.abant.org.br/informacoes/ informativos/informativos_1403.shtml>. Acesso em: 10 mar. 2005.

CARVALHO, J. M. D. Genocídio racial estatístico. O Globo, Rio de Janeiro, p. 7, 27 dez. 2004.

\footnotetext{
2 "O Presidente da ABA recebeu ofício do Presidente da Funai, Eduardo Almeida, datado de 29 de maio de 2003, no qual este agradece a atenção dispensada pela ABA à Funai por ter indicado antropólogos para realizar estudos sobre grupos que reivindicam reconhecimento oficial, e informa que a Funai está acatando, a partir de agora, o que preconiza a Convenção no 169 da OIT, que recomenda a auto-identificação como critério fundamental para o reconhecimento da identidade étnica de um grupo.” (Associação Brasileira de Antropologia, 2003).

3 O mais recente relatório (2004) da PNUD sobre desenvolvimento humano tem como subtítulo: "Liberdade Cultural num Mundo Diversificado". A mensagem desse relatório, por mais que reconheça os perigos da "essencialização" da cultura, é de que sem diversidade cultural não há desenvolvimento.
} 